\title{
Exploring Students' Difficulties in Speaking English and Their Attitude In Speaking English
}

\author{
Ratih Inayah, S.Pd, M.Pd \& Ida Lisdawati, M.Hum \\ ratih.inayah@gmail.com \\ STKIP Siliwangi Bandung
}

\begin{abstract}
The purpose of English language education is to provide students with the capabilities to understand the language in appropriate way and to have good ability in written and oral (Richard, 2008). If students are not able to speak English fluently and clearly, this purpose will be hard to achieve. So, it is essential to study this phenomenon in order to discover if students actually have problems with speaking, and then we can recognize what kind of problems and the reason of it also their perception in Speaking English as a foreign language in Indonesia. This study employed qualitative research paradigm as an intensive, holistic description, and analysis of a single instance, phenomenon, or social unit (Alwasilah, 2011). The study employed a descriptive method with multi instruments as observation, questionnaires, and interviews. Populations of this research were taken from a class of last semester students at STKIP Siliwangi Bandung and the sample were taken from four high achievers and four low achievers from the classroom. The result showed that students' behavior lead them to speaking difficulties, those who are not interested in speaking activity, relatively get trouble in speaking for academic purposes. This study showed that students who experience difficulties with speaking often have problems with their motivation and self-confidence so that they feel quite hard to recognize their true skill. Somehow, many students have positive attitude and perception toward the concept of fluency in speaking English. They consider that fluency in speaking is something important to master; they think it will be very useful for their carrier in the future.
\end{abstract}

Keywords : Speaking English, Difficulties

\section{Introduction}

Students at English major must master English in both written and oral communication, because the aim of English language education is to provide students with the capabilities to understand the language and the ability to both write and speak it (Richard, 2008). If students are not able to speak English fluently and clearly, this aim is hard to achieve. So, it is important to study this issue in order to discover if students actually have problems with speaking English, and if they do then we can recognize the kinds of problems and the reason that make it happened. Somehow, since there are some students who have problems with speaking, they must be able to demonstrate their speaking skill in 
front of many people in the future. For example, the prerequisite of finishing their study is they have to write a mini thesis and after that they still have to defense their argumentation orally in oral examination. That's why speaking as oral communication plays an important role in students' academic life and their daily life.

The phenomena that the researchers see nowadays, some students understand the English language very well but then feel difficult and uncomfortable when they have to speak English. They are in doubt to express their sentences in English. However, they have to Speak English in appropriate way and understandable. Moreover, they are students of English major who will be English teachers in the future.

Richards and Renandya(2002) stated that one implication of teaching and learning activity is focusing on both the forms of language and the functions of learning a language itself. In teaching oral communication, it's better if we don't limit students' attention and opportunity to be immersed in the language.

Referring to those explanations above, the study were conducted to seek the students' difficulties in speaking English and to know their attitude and perception toward speaking English as a foreign language in Indonesia.

Therefore, the research questions are:

1. What are students' difficulties when they have to Speak English?

2. What are students' attitude and perceptions about speaking English as a foreign language in Indonesia?

The aims of the study are:

1. To explore and discover whether the students experience difficulties in speaking English

2. To know their attitude and perception in speaking English as a foreign language in Indonesia.

The teaching and learning of speaking skills have a very essential role in using a language as a tool for communication. According to Brown (2008) speaking skills and communication are closely intertwined and strengthen each other. The interaction of speaking as performance applies especially strongly to conversation. In the classroom, speaking is a skill that is most widely used for classroom interaction. In daily life, the skills of speaking are very useful to build a good or positive impression when we meet new people for the first time; it's also very good to build and maintain professional relationship at works.

The importance of communication in language learning can be so meaningful; through reception we internalize linguistic information without which we could not produce language. "In classrooms, students always do more listening than speaking "(Brown, 2007). The researchers consider this as phenomenon, 
where some students somehow feel safer to listen than to speak. The teachers already give opportunity for students to speak English in the classroom, however only few students can do it bravely.

The mastery of speaking skills in English is a priority for many foreignlanguage learners. Consequently, learners often evaluate their success in language learning as well as the effectiveness of their English course on the basis of how much they feel they have improved in their spoken language proficiency. Teachers and textbooks make use of a variety of approaches, ranging from direct approaches focusing on specific features of oral interaction (e.g., turn-taking, topic management, and questioning strategies) to indirect approaches that create conditions for oral interaction through group work, task work, and other strategies (Richards, 1990).

Subsequent pedagogical research on speaking skill made significant refinements in the process of speaking. Studies looked at the effect of a number of different contextual characteristics and how they affect the speed and efficiency of processing oral communication. According to Rubin (1994) there are five factors of speaking process elements; the first factor is pronunciation, the second factor is interlocutor, the third factor is environment, and the fourth factor is confidence, and last is process characteristics. Mental process also becomes important element process in the language and learning of speaking. As we know that a person who speaks foreign language for the first time needs so much effort and courage to do it confidently, especially when they are adult learners.

According to Richards (1990) 'the conversation class is something of an enigma in language teaching". It is clear that the goals and the techniques for teaching conversation are very diverse; it depends on the student, teacher, and overall context of the class. Pronunciation is also cannot be separated with the learning of speaking, even phonological details can be so meaningful in speaking English.

It is now very clear that fluency in speaking English and accuracy are both important goals to be achieved in communicative language teaching. While fluency, may we find if someone can master communicative language courses such as phonology, grammar, and discourse in their spoken output.

The affective factors can be one of the major obstacles to speak English fluently (Brown 2007). Because of the language ego that informs people that "you are what you speak", so it makes students afraid of the judgment of the hearer. Very often, we can recognize whether someone is educated or uneducated from the way she or he speaks and the content of the speaking itself.

The interaction effect is also very important in speaking, the hardest part is because the learners must recognize the multiplicity of sounds, words, phrase, and discourse forms that characterize any language, at the same time the learner must create interactive communication. In other words, one learners' performance is always colored by interlocutor he or she is talking with. In real life, we will be very glad if we can speak to an interactive interlocutor rather than the silent one. 
Because speaking is two ways communication, where there must be at least a speaker and a listener, so that it can be a communicative dialogue.

The teaching of speaking in target language should enable the students to use the language orally for many purposes. The success of the teaching-learning process can be achieved if the teacher can present the materials in such a good way that can increase the students' interest. The teacher should be creative in presenting English to the students. They also have to practice various techniques of teaching, carefully select the materials, and use interesting instructional media that are suitable for the students in order to help them to speak in the language. Harmer (2001) states that there are many classroom speaking activities that can be used in teaching a language, such as acting from the script, communication games, discussion, prepared talks, as well as simulation and role play. In every classroom speaking activity, teacher must give students opportunity to speak what is in their mind, just like what is important and interesting for them to talk. It's better if teacher give students opportunity to express their understanding in English.

In EFL classroom, the challenge may be happened in teaching and learning English. EFL students need more effort to learn listening and speaking because they don't live in a country which uses English as a main tool for communication. So, EFL students must search the way to be immersed in English in so many ways, participating in the classroom may be the appropriate way to practice speaking skill. In Indonesia, being an English student major means that the student must open his or her mind to media, such as printed media and electronic media which use English as the main language. So it needs so much motivation and efforts.

According to Eric (2014) "EFL is an abbreviation for "English as a Foreign Language". This is mainly used to talk about students (whose first language is not English) learning English while living in their own country. (For example, an Indonesian learning English in Indonesia.) While Eric also stated that "ESL is an abbreviation for "English as a Second Language". This is mainly used to talk about foreign students learning English while living in an English-speaking country. (For example, an Indonesian learning English in America or Australia).

\section{Research Methodology}

This study employed qualitative research paradigm for a classroom setting. According to Alwasilah (2001), the classroom qualitative research has many advantages. The study is based on descriptive method, according to Alwasilah (2011) the descriptive method is claimed to have some benefits. The first is it goes deeply to the topic measured, it is to ensure a depth discussion on the topic. The second is it provides the researcher with data recorded, so it makes that possible for researcher to revise the data obtained in order to have in depth 
analysis. As a case study, the present study is contextual and will be conducted in specific situation.

Research question number one and two are answered qualitatively. This research was conducted to find out students' difficulties when practicing speaking material used in their class, also to know about their perception about the concept of fluency of speaking English as a foreign language. Clearly, observational studies have been fundamental to this qualitative research. This study combines observation with interviewing, also questionnaire. This is because we have some research questions and because we want to use different methods or sources to strengthen each other so that we are using some form of methodological triangulation (Silverman, 2005).

Site and Participants

This research was conducted in STKIP Siliwangi Bandung. The population of this study are students of English Education Study Program class A3 register year of 2013, they have already taken English for Academic Purposes Subject in the previous semester. The samples were taken from four high achievers and four low achievers from the classroom.

The setting of the research used both 'closed' or 'private' setting where access is controlled by gatekeepers, also 'open' or 'public' settings where access is freely available but not always without difficulty either practical or ethical.

The procedures of the research are as follow.

First of all, the researchers prepared the instruments to be used in the research. In the same weeks we also recruited the participants and asked them to be participated in the study. Once this was completed, then the researchers begin to collect data.

Next, the questionnaires were then given to the students, after that the interviews were given to get more information. We tried to conduct a focus interview where we keep on to the issue, we interviewed the students, and we asked them that the question we analyzed was focus interview is to get students' understanding. Then the researchers code the answers of the students.

In this qualitative research, "ethical issues are very essential" (Silverman, 2005). For example, as a qualitative researchers who study human subjects often find dilemma of wanting to give full information to subjects but not 'contaminating' our research by informing subjects too specifically about the research question to be studied.

Moreover, when we are studying people's behavior or asking them questions, not only the values of us as the researchers but also our responsibilities to those studied have to be kept. A way to keep participants' privacy is to let them know that we have ethical code in conducting research. 


\section{Findings and Discussion}

This study has showed a meaningful insight into the academic speaking practices of STKIP Siliwangi students. It does not generalize these findings beyond the College but some significant findings are present in this study. In our findings, students' behavior lead them to speaking difficulty, those who do not like speaking English activity, relatively get trouble in speaking for academic purposes. This study showed that students who experience difficulty with speaking often have problems with motivation and self-confidence. Individuals with speaking problems are more likely to attribute failure to a lack of personal ability and the things that make them hard to recognize their true skill. The connection between speaking difficulty and self-confidence related specially with students' feeling, especially their role as speakers. It is our duty as a teacher to motivate students to be more pay attention when they must listen to materials, and our duty as teacher too, to make students more confident to speak up what is important and interesting for them.

Students' Efforts to Solve the Problems

This study has identified some characteristics that differentiate high achievers from the low achievers. Both low achievers and high achievers, they try speak English appropriately. Somehow, low achievers tend to be focus on find the meaning of single words, often fail to correct their listening and speaking skill for different purposes. Low achievers tend to be less strategic. For example, low achievers focus energy on looking busy and following directions, but remain less aware of comprehension difficulties or strategies to understand the whole context. In fact, when given chance to start the communication, low achievers do not brave to start a conversation, and they fail to ask questions or request assistance to clarify difficulties. Low achievers believe that the purpose of speaking is only to pronounce words correctly. When asked to speak, they often doubt to speak up their mind.

In contrast, high achievers use efficient strategies that rely more on processing in an interactive communication. They aware that listening and speaking is intertwined, so they give more attention and willingness to speak up their mind in classroom activities. Furthermore, high achievers conclude information accurately, clarify difficulties in appropriate way, and predict what is likely to come next. High achievers understand that making sense out of listening and speaking is important to comprehend a whole context of conversation and to reach a successful interaction. In conclusion, high achievers are seen as very active and strategic listener and speaker, they understand the purpose of listening and speaking in oral communication, they continuously pay attention to their comprehension, their fluency, and they brave to take corrective action when comprehension failure happens. The researchers emphasize that high achievers learn much more than low achievers do. 
Students' Attitude toward the Concept of Fluency of Speaking English as a Foreign Language

In the questionnaire, there were fifteen statements which covered the components of perceptions. The students' responses to items were recapitulated by using likert scale and the data were then analyzed and interpreted.

To answer research question 'What are students' perception about the concept of fluency of speaking English as a foreign language?' A questionnaire was given to twenty five students. If the statement is positive, it means that the scale is Strongly agree $=5$, Agree $=4$, Neutral $=3$, Disagree $=2$, Strongly disagree $=$ 1. While if the statement is negative, it means that the scale is Strongly agree $=1$, Agree $=2$, Neutral $=3$, Disagree $=4$, Strongly disagree $=5$

The lowest score was 375, while the higher score was 1879

After the answers of the 40 students were calculated, then it found that the result of students' answer is 1350 .

Table 3.1 Students' Attitude Toward the Concept of Fluency of Speaking English as a foreign language

\begin{tabular}{|c|c|c|}
\hline No & Range & $\begin{array}{c}\text { Student's } \\
\text { Attitude Level }\end{array}$ \\
\hline 1 & $\mathbf{3 7 5 - 6 7 5}$ & Very negative \\
\hline 2 & $\mathbf{6 7 6 - 9 7 6}$ & Negative \\
\hline 3 & $\mathbf{9 7 7 - 1 2 7 7}$ & Neutral \\
\hline 4 & $1278-1578$ & Positive \\
\hline 5 & $\mathbf{1 5 7 9 - 1 8 7 9}$ & Very positive \\
\hline
\end{tabular}

According to the table, 1350 is included to positive level, because positive level is in Range 1278-1578. So, it means many students have positive attitude and perception toward the concept of fluency of speaking English as a foreign language. They know about the importance of fluency in speaking English. Fluency in speaking English will be very useful for their carrier in the future as an English teacher.

\section{Conclusion}

Teaching English in a world of change and challenge is a very complex process. Somehow, oral communication can be so interesting and important to learn. The result indicated that students' behavior toward speaking lead them to have difficulty in speaking for academic purposes. Subjects in low achievers spent less time in speaking activity and they pay a little attention to speaking activity in the classroom. However subjects in high achievers spent more time in listening and speaking activity, high achievers always learn much more than low 
achievers. Somehow most of the students (70\%) have a positive attitude and perception toward the concept of fluency in speaking English, they think that fluency in speaking English is something important to achieve for their academic life as a student and or their carrier as English teacher in the future. In conclusion, speaking English can be seen as a very essential life skill and activities which we use in academic life and in our daily life. Very often, we need to speak English clearly and understandable, so that the purpose of English education can be achieved. Students need to realize that speaking English is not only life style but also a necessity or requirement. 


\section{References}

Alwasilah, A.Chaedar. 2011. Pokoknya Kualitatif: Dasar-dasar Merancang dan Melakukan Penelitian Kualitatif. Bandung. Pustaka Jaya

Brown, H.D. 2007. Teaching By Principles: An Interactive Approach to

Language Pedagogy ( $3^{\text {rd }}$ edition). White Plains, NewYork: Pearson Education.

Clark, H. M., and E. V. Clark .1977. Psychology and Language: An Introductio to Psycholinguistics. New York: Harcourt Brace Jovanovich.

Harmer J.1991. The Practice of English Language Teaching. London: Longma Group U.K.Limited.

Richards, Jack C. 2008. Teaching Listening and Speaking From Theory $t$ Practice. New York: Cambridge University Press.

Richards, Jack C\& Renandya, Willy A. 2002. Methodology in Languag Teaching. New York: Cambridge University Press.

Rubin, J. 1994. A Review of Second Language Listening Comprehension Reseacrch. Modern Language Journal, 78 (2), 199-217

Silverman, David. 2005. Doing Qualitative Research: A Practical Handbook. London. Sage Publications Ltd. 
APPENDIX

QUESTIONNAIRE

\begin{tabular}{|c|c|c|c|c|c|}
\hline Statements & $\begin{array}{l}\text { Strongly } \\
\text { disagree }\end{array}$ & disagree & Neutral & agree & $\begin{array}{l}\text { Strongly } \\
\text { agree }\end{array}$ \\
\hline \multicolumn{6}{|l|}{ Affective } \\
\hline \multicolumn{6}{|l|}{ 1. I like speaking subject } \\
\hline \multicolumn{6}{|l|}{$\begin{array}{l}\text { 2. Speaking English to } \\
\text { other people makes } \\
\text { me happy }\end{array}$} \\
\hline \multicolumn{6}{|l|}{$\begin{array}{l}\text { 3. Speaking English } \\
\text { gives me } \\
\text { opportunities to listen } \\
\text { to other people and at } \\
\text { the same time I learn } \\
\text { English and moral } \\
\text { values }\end{array}$} \\
\hline \multicolumn{6}{|l|}{$\begin{array}{l}\text { 4. Speaking English } \\
\text { creates a lively and } \\
\text { enjoyable classrooms } \\
\text { atmosphere }\end{array}$} \\
\hline \multicolumn{6}{|l|}{$\begin{array}{l}\text { 5. I am confident that I } \\
\text { can speak English } \\
\text { through dialogue very } \\
\text { well }\end{array}$} \\
\hline \multicolumn{6}{|l|}{ Behavioral } \\
\hline \multicolumn{6}{|l|}{$\begin{array}{l}\text { 6. Speaking English } \\
\text { arouses my } \\
\text { motivation and } \\
\text { learning interest }\end{array}$} \\
\hline \multicolumn{6}{|l|}{$\begin{array}{l}\text { 7. Speaking for } \\
\text { Academic Purposes is } \\
\text { important subject to } \\
\text { learn }\end{array}$} \\
\hline \multicolumn{6}{|l|}{$\begin{array}{l}\text { 8. I will not need much } \\
\text { speaking English } \\
\text { when I get out of } \\
\text { college }\end{array}$} \\
\hline $\begin{array}{l}\text { 9. I need Speaking } \\
\text { English for my future } \\
\text { career }\end{array}$ & & & & & \\
\hline $\begin{array}{l}\text { 10. Speaking English to } \\
\text { other people arouses }\end{array}$ & & & & & \\
\hline
\end{tabular}




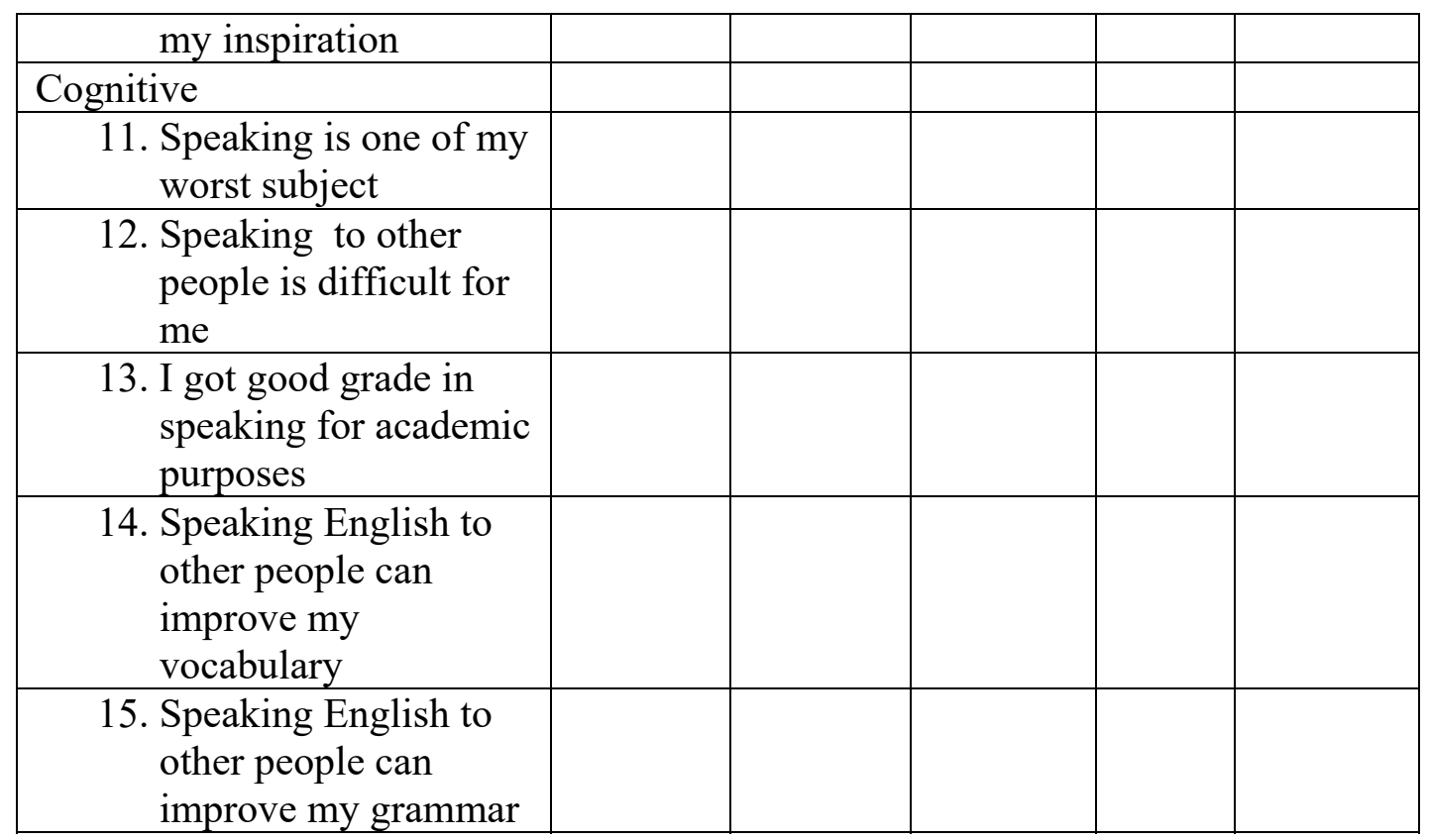

Adapted from: Attitudes and Opinions written by Stuart Oskamp and P.Wesley Schultz

\section{INTERVIEW QUESTIONS}

\section{Background}

1. Age:

2. Gender:

3. Urban/rural background:

4. Mother Tongue:

5. Occupation:

6. Education:

7. Parents' education and occupation:

8. What do you study at STKIP SILIWANGI?

9. What languages do you speak?

10. What kind of a speaker are you in your own language? E.g. what have people close to you/your teachers said? Are you a fast or a slow speaker, do you think carefully before speaking, do you talk a lot?

\section{English education}

1. How long have you studied English?

2. How do you feel about studying English?

3. What kind of English teachers/education have you had?

4. Have you rehearsed speaking in English on your English courses? How?

5. Do you think that your English teachers have favoured a particular way of speaking/accent, for example an American accent? 


\section{Use of English}

1. Do you use English a lot? How/Where? Do you speak it a lot?

2. Do you need English at work? What for?

3. Have you used/do you use English with your family?

4. Have you ever lived abroad or do you travel a lot?

5. Do you speak English with pleasure?

6. What kind of experiences do you have on speaking English? Positive/negative?

7. Is English difficult to understand? (Listening, reading)

8. Is speaking English difficult?

9. What accent do you like?

10. What accent do you dislike?

Adapted from: Culturally Speaking written by Genzel, R.B \& Cummings, M.G 